\title{
Effects of the "Social Responsibility for Health" program on adolescents' empathic skills, altruistic and health perception
}

\author{
"Sağlığa Yönelik Sosyal Sorumluluk" programının ergenlerin empatik eğilim, özgecilik \\ ve sağlık algısına etkisi
}

Ayşe ŞENGEL, Kamer GÜR

\begin{abstract}
Objectives: This study aims to determine the effect of the "Social Responsibility for Health (SRFH)" program implemented under the leadership of a school nurse on adolescents' empathic skills, altruism and health perception.

Materials and Methods: This semi-experimental study used the pre test-post test control group design. It was conducted among 116 adolescents attending a private high school in Istanbul. Fifty-six and 60 of the participants were randomly assigned to the control and experimental groups, respectively. The SRFH program was completed in 14 weeks. The data were collected with the Empathic Tendency Scale, the Scale of Altruism, and the Health Perception. Parametric tests (unpaired t-test and paired t-test ) were utilized in the data analysis.

Results: While there was no significant difference between the experimental and control groups' total pretest scores of empathic skills and health perception $(P>0.05)$, a significant difference was found between both groups' total posttest scores $(P=0.00 ; P=$ $0.05)$. Furthermore, the experimental group's total posttest score of altruism and their score averages of social and helpfulness subdimensions increased $(P=0.03 ; P=0.01 ; P=0.02)$.

Conclusion: The SRFH program implemented under the leadership of a school nurse increased adolescents' empathic skills and health perception and created a difference between the experimental and control groups.
\end{abstract}

Keywords: Social responsibility, Adolescent, Empathy, Altruism, Health perception

Ayşe Şengel( $\square)$

School Nurse, Açı Schools, Istanbul, Turkey

e-mail:ayse.sengel@acischools.k12.tr

Kamer Gür

Department of Nursing , Faculty of Health Sciences, Marmara University, Istanbul, Turkey

Submitted / Gönderilme: 30.08.2017

Accepted/Kabul: 06.11.2017
ÖZ

Amaç: Bu çalışmanın amacı, bir okul hemşiresi liderliğinde uygulanan "Sağlığa Yönelik Sosyal Sorumluluk (SYSS)" programının ergenlerin empatik eğilim, özgecilik ve sağlık algısına etkisini belirlemektir.

Gereç ve Yöntem: Yarı deneysel bu çalışma, ön test - son test kontrol gruplu olarak tasarlandı. İstanbul'da bir özel lisede öğrenim gören 116 ergenle yapıldı. Katılımcıların 56'sı kontrol, 60'1 girişim gruplarına rastgele atandı. SYSS programı 14 haftada tamamland1. Veriler, Empatik Eğilim Ölçeği, Özgecilik Ölçeği ve Sağlık Algısı Ölçeği kullanılarak toplandı. Analizde parametrik testler (unpaired t-test and paired t-test) kullanıld1.

Bulgular: "Sağlığa Yönelik Sosyal Sorumluluk" programı öncesi girişim ve kontrol grubunun empatik eğilim ve sağlık algısı toplam puanları arasında fark yok iken $(P>0.05)$, son testte iki grubun toplam puanları arasında istatistiksel olarak anlamlı fark bulunmuştur ( $P=0.00 ; P=0.05)$. Ayrıca, program sonrasında, girişim grubunun özgecilik toplam puanı, sosyal ve yardımseverlik alt boyut puan ortalamaları yükselmiştir $(P=0.03 ; P=0.01 ; P=0.02)$.

Sonuç: Bir okul hemşiresi liderliğinde uygulanan SYSS programı ergenlerin empatik eğilimlerini ve sağlık algılarını artırmış, girişim ve kontrol grupları arasında fark yaratmıştır.

Anahtar kelimeler: Sosyal sorumluluk, Ergen, Empati, Özgecilik, Sağlık alg1sı

\section{Introduction}

While transitioning from the $20^{\text {th }}$ century to the $21^{\text {st }}$ century, values have been changing rapidly, what is natural has been replaced by what is artificial and what is real by what is virtual and individuals have been experiencing difficulty in adapting to this rapid change [1]. Value judgments of individuals are also influenced by mass and social changes. Industrialization and urbanization have pushed the individual towards devaluation within crowded groups and while technological advancements have been accelerating the information share, this virtual environment has made values such as helpfulness, compassion and empathy. Whereas, subjects such as adaptation to society, honesty, caring about 
family and relative relations, taking responsibility, mercy, face to face communication were in the forefront prior to $2000 \mathrm{~s}$, subjects including confidence, courage, individualization, speed, competition and virtual communication can be deemed more important by the new generation which has been born into the virtual world with the technology. Adolescents are the group which has been influenced by this change the most and the fastest. Born into such a volatile environment, trying to create their own identities, adolescents have been finding it harder to find the basic values on which they will base their lives [2]. Every individual has the potential and responsibility to influence the development of their environment within their own limits [3]. It is aimed with social responsibility projects to help youngsters learn and improve by taking charge in conscious and planned projects for their society [4]. Today, social support and education is much needed for the sense of social responsibility to establish and develop [5]. It has been seen in previous research studies that individual's education and socialization have a distinct role in the formation of the sense of responsibility [6]. Therefore, children and youngsters should be allowed to use their knowledge and competences they get during their education to provide solutions for real problems and to socialize [4]. Social responsibility programs have been becoming more and more important in the educational institutions [7]. When considering the school period as a process during which individuals' behaviors develop and become mature, it is to be remembered that especially adolescence is an important period in the development of positive social behaviors [8]. Social responsibility problems are quite important for adolescents in terms of caring about the society and the world, having the sense of social responsibility and putting forth one's own approach [4].

Previous research has shown that including adolescent individuals in social responsibility programs contribute to the development of their interpersonal communication skills, their self-development and social coherence, emotional satisfaction and good feelings, solidarity, ability to provide solutions to problems, leadership qualities and the development of confidence and empathy skills [9-11]. Social responsibility projects affect students conceptual skills and intellectual development positively to support their academic achievements, enhance confidence, achieve self-actualization and help learn new situations in the new world by experiencing them and provide them with the adaptation skill [12]. In addition, children and youngsters would have knowledge about their own culture, reinforcing their awareness of their culture as they learn about it. They can evaluate the way they live and how to live thanks to this awareness. They can think more clearly and creatively when they are aware of their emotions and keep them under control; they can manage their stress and hardships; they can communicate with others in a better way; they can show trust and empathy; they can face social problems to find opportunity to think over and discuss them [4, 13, 14].

In consideration of the fact that adolescents spend most of their time at school in a day, it is considered necessary to include social responsibility projects for health in studies conducted under the leadership of the school nurse. It is aimed with the "Social Responsibility for Health" program to increase adolescents' empathic skills towards special groups in the society such as patients and disabled individuals, to make them look at social groups in need rather within the sense of helpfulness and responsibility and to provide them with positive health behaviors so they can protect and enhance their own health through participation in the program [15].

While several positive impacts of social responsibility programs on students were seen in the literature review, no study which was based in school and conducted under the leadership of a nurse with students was observed.

This study was carried out to determine the effect of the SRFH program implemented under the leadership of the school nurse on adolescents' empathic skills, altruism and health perception.

\section{Materials and Methods}

This semi-experimental study used the pretest-posttest control group design. It was carried out with 116 adolescents who were attending a private high school affiliated with the Ministry of National Education in Istanbul in the academic year of 2014-2015. A hundred and sixteen adolescents were randomly included in the control $(n=56)$ and experimental $(n=60)$ groups, and the participation was based on voluntariness and parental consent. The SRFH program was implemented in the experimental group for 12 weeks and the program was completed in 14 weeks. The data collection instrument used included the 26-question socio-demographic questionnaire, the Empathic Skill Scale, the Scale of Altruism and the Health Perception Scale. The Empathic Skill Scale is a 5-point Likert type scale developed by Dökmen. The scale comprises of 20 items. Higher scores in the questionnaire mean higher empathic skill. Its Cronbach's Alpha coefficient is 0.82 [16]. The Scale of Altruism is a 5-point Likert type scale developed by Perry London and Robert K. Bower. Its Turkish reliability and validity studies were conducted by 
Cantez, Aşkın and Akbaba. The scale comprises of 20 items. Individual's altruism score is calculated by adding the scores in the marked choices. Its Cronbach's Alpha coefficient is 0.85 [17]. The Health Perception Scale is a 5-point Likert type scale developed by Diamond et al. [20]. Its Turkish reliability and validity studies were conducted by Kadıoglu and Yildiz [18]. The scale is composed of 15 items that involve positive and negative statements. The lowest score that can be obtained in the scale is 15 and the highest one is 75. Its Cronbach's Alpha coefficient is 0.77 [18]. The data were collected in the classroom setting under the researcher's supervision. Parametric tests (unpaired t-test and paired t-test ) were utilized in the data analysis. "Percent of change" was calculated to compare how the difference occurred between the two groups (control and experimental) (Percent of change $=(($ pre-value - post-value $) /$ pre-value $) * 100$ per person. The statistical significance level was accepted to be $P<0.05$.

The research hypotheses are as follows: Following the SRFH program:
H1: There is a difference between the experimental and control groups by the empathic skill.

H1: There is a difference between the experimental and control groups by altruism.

H1. There is a difference between the experimental and control groups by health perception.

The purpose of the SRFH program is to increase adolescents' empathic skills towards special groups in the society such as patients and disabled individuals, to make them treat social groups in need rather within the sense of helpfulness and responsibility and to provide them with positive health behaviors so they can protect and enhance their own health.

The program was created following an up-to-date literature review and as a production of the fact that adolescents provided opinions as decision makers in the planning stage. Both theoretical and applied practices were utilized together in the study.

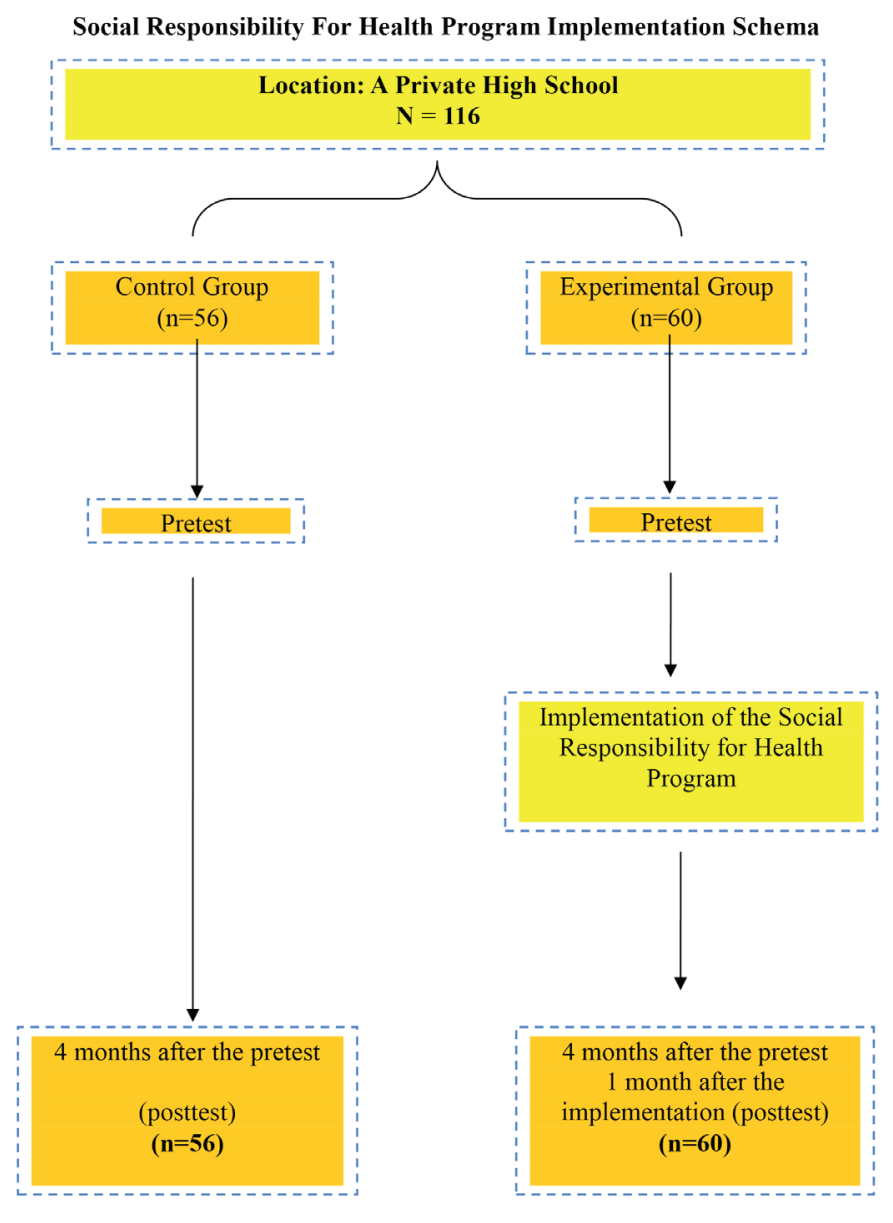

All activities were performed under the leadership of the school nurse in the 14-week program implementation.

Figure1. "Social Responsibility For Health Program" implementation schema 


\section{Implementation of "The Social Responsibility for Health" Program}

Week 1: Pretest was performed on the experimental and control groups. An introduction and adaptation meeting was held under the leadership of the school nurse.

Week 2: The experimental group was instructed. Definitions and importance of social responsibility, empathy, altruism and helpfulness were explained in the instruction. The program details were shared.

Week 3: Persons who have worked or are working in social responsibility projects gave a theoretical instruction to the adolescents.

Week 4: Information on the attributes of the hospitals to be visited and the rules to be followed was provided. Subjects of illness, health and approach towards patients were explained. The cartoon "Paul and the Dragon" which would be effective for the development of empathy, altruism and health perception was played.

Week 5: Information on the attributes of the disabled school to be visited and the rules to be followed was provided. A guest working at that school was invited. Subjects of disability and approach towards disabled individuals were explained.

Week 6-7 - 8: The adolescents were divided into three 20-individual groups and they completed their visits to different institutions each week. The purpose with the first visits to Pediatric Oncology Service, Pediatric Service, Mentally and Developmentally Disabled School was to learn about the institutions, visit the child/adolescent patients and disabled children there, make observations, develop empathy and produce ideas about the projects they would prepare.

Week 9: The adolescents found names that remind of the social responsibility concept for their groups and explained why they gave themselves those names. The chosen names included themes like friendship, hope, wishes, etc.

Week 10 - 11: The activities to be performed at the visited institutions were planned and the preparations were finalized.

Week 12: The hospital and the school were visited. A group prepared for the hospitalized children gave a guitar concert and it was ensured that the children sang along with the music. The adolescents spent one hour with their mentally disabled friends and their mothers at the playground in the vicinity. They shared the surprises they prepared by hand with their matched friends.

Week 13: Discussions were made through the activity videos. The adolescents discussed what they can do to protect and enhance their own health.

Week 14: The posttest was applied to the experimental and control groups and all participants were thanked.

Limitations: Randomization was not utilized when planning the research. The reason was that the control group was working in projects such as aid to schools, book collection, having state school students do homework, etc. by the nature of club activities at the institution even if these are not related to health. Another limitation is that the outcomes could not be generalized to all adolescents because the program was implemented in one school and the time spent at the visited institutions was restricted by the administration.

Prior to this study, permission was received from Ethical Council of Marmara University Institute of Health Sciences (26.11.20149). The participants and their parents were also informed to receive their consents.

\section{Results}

Fifty percent of 116 adolescents who participated in the study are girls and the other half is boys. $36.2 \%$ of them had no siblings while $11.2 \%$ were born in a foreign country. Parents of $18.1 \%$ lived separately. $85.3 \%$ of them were the members of a nuclear family, mothers of $89.7 \%$ have a bachelor's degree and more, and fathers of $92.2 \%$ have a bachelor's degree and more. $83.6 \%$ of them reported that their parents' financial status were good and better.

There is no statistically significant difference among gender $\left(\mathrm{x}^{2}=0.14 ; P>0.05\right)$, place of birth $\left(\mathrm{x}^{2}=0.57 ; P>0.05\right)$, whether parents are together $\left(\mathrm{x}^{2}=1.91 ; P>0.05\right)$, type of family $\left(x^{2}=2.15 ; P>0.05\right)$, mother's vocation $\left(x^{2}=0.04\right.$; $P>0.05)$, father's vocation $\left(x^{2}=0.08 ; P>0.05\right)$, mother's educational level $\left(\mathrm{x}^{2}=0.02 ; P>0.05\right)$, father's educational level $\left(\mathrm{x}^{2}=1.32 ; P>0.05\right)$, and parents' financial status $\left(\mathrm{x}^{2}=0.17 ; P>0.05\right)$. The experimental and control groups were found similar in the analyses performed by their demographics. 
Table I. Group comparison of the Empathic Skill Scale score averages

\begin{tabular}{|c|c|c|c|c|}
\hline \multirow[t]{2}{*}{ Empathic Skill } & Pretest & Posttest & $\begin{array}{l}\text { Pre-post test } \\
\text { Statistics }\end{array}$ & Percentage of change \\
\hline & Mean \pm SD & Mean \pm SD & t-test*; p & Mean \pm SD \\
\hline Experimental Group ${ }^{a}$ & $72.90 \pm 9.07$ & $75.00 \pm 8.14$ & $1.86 ; \mathbf{0 . 0 5}$ & $-3.88 \pm 1.28$ \\
\hline Control Group ${ }^{\mathrm{b}}$ & $70.12 \pm 10.4$ & $67.05 \pm 8.98$ & $2.25 ; \mathbf{0 . 0 2}$ & $2.94 \pm 1.51$ \\
\hline Statistics t-test ${ }^{* *} ; \mathrm{p}$ & $1.50 ; 4.99$ & $4.99 ; \mathbf{0 . 0 0}$ & & $-2.62 ; 0.01$ \\
\hline
\end{tabular}

${ }^{\mathrm{a}} \mathrm{n}=60$ adolescents, ${ }^{\mathrm{b}} \mathrm{n}=56$ adolescents* Paired Sample t-test**Unpaired t-test

While there was no significant difference between the experimental and control groups' total pretest scores of the Empathic Skill Scale before the SRFH program $(P>0.05)$, a significant difference was found between both groups' total posttest scores of empathic skill $(P=0.00)$. It was discovered that experimental group's empathic skill scores were increased after the SRFH and there was a statistically significant difference between the pretest and the posttest $(P=0.05)$. There is a statistically significant difference between the percent of change of the experimental and control group $(P=0.01)$ (Table I).

Table II. Group comparison of Score Averages of the Scale of Altruism and its Subdimensions

\begin{tabular}{|c|c|c|c|c|}
\hline \multirow{2}{*}{ Altruism } & Pretest & Posttest & Statistics & Percentage of change \\
\hline & Mean \pm SD & Mean \pm SD & t-test $;$ p & Mean \pm SD \\
\hline \multicolumn{5}{|l|}{ Altruism Total } \\
\hline Experimental Group ${ }^{\mathrm{a}}$ & $71.45 \pm 8.94$ & $74.30 \pm 9.19$ & $2.33 ; \mathbf{0 . 0 2}$ & $-5.00 \pm 14.7$ \\
\hline Control Group ${ }^{\mathrm{b}}$ & $66.32 \pm 8.89$ & $65.68 \pm 9.91$ & $0.46 ; 0.64$ & $-.06 \pm 16.4$ \\
\hline $\mathrm{t}_{\text {-test }}^{* *} ; \mathrm{p}$ & $3.09 ; \mathbf{0 . 0 2}$ & $4.86 ; 0.00$ & & $1.70 ; 0.09$ \\
\hline \multicolumn{5}{|l|}{ Family Dimension } \\
\hline Experimental Group ${ }^{a}$ & $19.80 \pm 2.91$ & $19.58 \pm .300$ & $0.53 ; 0.59$ & $0.02 \pm 1.56$ \\
\hline Control Group ${ }^{\mathrm{b}}$ & $18.36 \pm 2.84$ & $18.61 \pm 2.80$ & $-0.79 ; 0.43$ & $2.33 \pm 1.41$ \\
\hline t-test ${ }^{* *} ; \mathrm{p}$ & $2.69 ; 0.00$ & $1.80 ; \mathbf{0 . 0 0}$ & & $0.83 ; 0.40$ \\
\hline \multicolumn{5}{|l|}{ Social Dimension } \\
\hline Experimental Group $^{\mathrm{a}}$ & $16.58 \pm 3.58$ & $18.25 \pm 3.68$ & $-2.85 ; \mathbf{0 . 0 0}$ & $-16.21 \pm 44.2$ \\
\hline Control Group ${ }^{\mathrm{b}}$ & $15.34 \pm 3.99$ & $14.79 \pm 4.48$ & $0.90 ; 0.37$ & $-.94 \pm 36.3$ \\
\hline t-test ${ }^{* *} ; p$ & $1.76 ; 0.08$ & $4.55 ; \mathbf{0 . 0 0}$ & & $-2.02 ; 0.04$ \\
\hline \multicolumn{5}{|c|}{ Helpfulness Dimension } \\
\hline Experimental Group $^{\mathrm{a}}$ & $16.58 \pm 3.77$ & $17.95 \pm 3.96$ & $-2.52 ; 0.01$ & $-13.1 \pm 35.4$ \\
\hline Control Group ${ }^{\mathrm{b}}$ & $15.32 \pm 3.43$ & $14.77 \pm 3.59$ & $0.98 ; 0.32$ & $-0.16 \pm 29.6$ \\
\hline t-test ${ }^{* *} ; \mathrm{p}$ & $1.87 ; 0.06$ & $4.51 ; \mathbf{0 . 0 0}$ & & $-2.13 ; \mathbf{0 . 0 3}$ \\
\hline \multicolumn{5}{|c|}{ Responsibility Dimension } \\
\hline Experimental Group $^{\mathrm{a}}$ & $18.48 \pm 2.41$ & $18.52 \pm 2.93$ & $-0.80 ; 0.93$ & $-1.32 \pm 17.9$ \\
\hline Control Group ${ }^{\mathrm{b}}$ & $17.30 \pm 3.26$ & $17.52 \pm 2.46$ & $-0.46 ; 0.64$ & $-5.06 \pm 28.9$ \\
\hline t-test ${ }^{* *} ; \mathrm{p}$ & $2.22 ; 0.02$ & $1.98 ; \mathbf{0 . 0 5}$ & & $0.84 ; 0.40$ \\
\hline
\end{tabular}

${ }^{\mathrm{a}} \mathrm{n}=60$ adolescents, ${ }^{\mathrm{b}} \mathrm{n}=56$ adolescents $*$ Paired Sample t-test** Unpaired t-test 
A significance difference was found before the SRFH program between the experimental and control groups by the total altruism scores and score averages of its subdimensions $(P=0.01 ; P=0.00 ; P=0.02 ; P=0.04 ; P=0.04)$. That significant difference went on in all subdimensions except the total altruism score in the posttest $(P=0.11 ; P=0.00$; $P=0.05 ; P=0.00 ; P=0.00)$. The experimental group's total posttest score of altruism and their score averages of social and helpfulness subdimensions in the posttest increased, and this difference was found significant $(P=0.03 ; P=0.01$; $P=0.02$ ) (Table II).

A significance difference was found before the SRFH program between the experimental and control groups by the total altruism scores and score averages of its subdimensions (except Social Dimension and Helpfulness Dimension) ( $P=0.02 ; P=0.00 ; P=0.08 ; P=0.06 ; P=0.02)$. That significant difference went on in all subdimensions score in the posttest $(P=0.00 ; P=0.00 ; P=0.00 ; P=0.00$; $P=0.05)$. The experimental group's total posttest score of altruism and their score averages of social and helpfulness subdimensions in the posttest increased, and this difference was found significant $(P=0.02 ; P=0.00 ; P=0.01)$.

A statistically significant difference was found in the subdimensions of Social Dimension and Helpfulness Dimension and between percent of change of the experimental and control group $(P=0.04 ; P=0.03$ ) (Table II).

Table III. Group comparison of Score Averages of the Health Perception Scale and its Subdimensions

\begin{tabular}{|c|c|c|c|c|}
\hline Health Perception & $\begin{array}{c}\text { Pretest } \\
\text { Mean } \pm \text { SD }\end{array}$ & $\begin{array}{c}\text { Posttest } \\
\text { Mean } \pm \text { SD }\end{array}$ & $\begin{array}{l}\text { Statistics } \\
\text { t-test*; p }\end{array}$ & $\begin{array}{l}\text { Percentage of change } \\
\text { Mean } \pm \text { SD }\end{array}$ \\
\hline \multicolumn{5}{|c|}{ Health PerceptionTotal } \\
\hline Experimental Group ${ }^{\mathrm{a}}$ & $54.85 \pm 6.22$ & $56.97 \pm 5.56$ & $-2.75 ; 0.00$ & $-4.67 \pm 11.65$ \\
\hline Control Group ${ }^{\mathrm{b}}$ & $54.30 \pm 8.05$ & $54.41 \pm 6.94$ & $-0.10 ; 0.91$ & $-1.46 \pm 14.33$ \\
\hline t-test ${ }^{* *} ; \mathrm{p}$ & $0.41 ; 0.68$ & $2.19 ; \mathbf{0 . 0 3}$ & & $-1.32 ; 0.18$ \\
\hline \multicolumn{5}{|l|}{ Importance of Health } \\
\hline Experimental Group ${ }^{\mathrm{a}}$ & $10.93 \pm 2.66$ & $11.67 \pm 2.05$ & $-2.36 ; \mathbf{0 . 0 2}$ & $-11.5 \pm 26.9$ \\
\hline Control Group ${ }^{\mathrm{b}}$ & $10.91 \pm 2.31$ & $10.80 \pm 2.32$ & $0.37 ; 0.70$ & $-1.28 \pm 22.3$ \\
\hline t-test ${ }^{* *} ; \mathrm{p}$ & $0.49 ; 0.96$ & $2.19 ; \mathbf{0 . 0 3}$ & & $-2.22 ; \mathbf{0 . 0 2}$ \\
\hline \multicolumn{5}{|l|}{ Self-awareness } \\
\hline Experimental Group ${ }^{a}$ & $12.08 \pm 1.89$ & $12.30 \pm 1.68$ & $-0.76 ; 0.44$ & $-3.94 \pm 19.9$ \\
\hline Control Group ${ }^{\mathrm{b}}$ & $11.57 \pm 2.58$ & $11.57 \pm 1.89$ & $-0.01 ; 0.99$ & $-5.65 \pm 39.2$ \\
\hline t-test ${ }^{* *} ; \mathrm{p}$ & $1.22 ; p=.22$ & $2.19 ; \mathbf{0 . 0 3}$ & & $0.29 ; 0.76$ \\
\hline \multicolumn{5}{|l|}{ Center of Control } \\
\hline Experimental Group ${ }^{\mathrm{a}}$ & $18.07 \pm 3.42$ & $18.65 \pm 3.23$ & $-1.75 ; p=0.08$ & $-4.58 \pm 16.2$ \\
\hline Control Group ${ }^{\mathrm{b}}$ & $18.16 \pm 3.27$ & $18.46 \pm 3.56$ & $-0.73 ; p=0.46$ & $-2.91 \pm 17.5$ \\
\hline t-test ${ }^{* *} ; \mathrm{p}$ & $-0.15 ; 0.88$ & $0.29 ; 0.76$ & & $-0.53 ; 0.59$ \\
\hline \multicolumn{5}{|l|}{ Certainty } \\
\hline Experimental Group ${ }^{\mathrm{a}}$ & $13.77 \pm 3.42$ & $14.35 \pm 2.99$ & $-1.20 ; p=0.23$ & $-9.26 \pm 29.9$ \\
\hline Control Group ${ }^{\mathrm{b}}$ & $13.66 \pm 3.53$ & $13.57 \pm 3.15$ & $-1.86 ; p=0.85$ & $-4.28 \pm 29.6$ \\
\hline t-test ${ }^{* *} ; p$ & $0.16 ; 0.87$ & $1.36 ; 0.17$ & & $-.89 ; 0.37$ \\
\hline
\end{tabular}

${ }^{\mathrm{a}} \mathrm{n}=60$ adolescents, ${ }^{\mathrm{b}} \mathrm{n}=56$ adolescents*Paired Sample t-test** Unpaired $\mathrm{t}$-test 
Whereas, there was no difference between the experimental and control groups by total health perception scores $(P>0.05)$, adolescents' posttest scores in the experimental group was found to be higher than and significantly different from adolescents' posttest scores in the control group ( $P=0.03$ ). Experimental group's post-SRFH program health perception scores increased and a statistically significant difference was found $(P=0.00)$. While no difference was found between the experimental and control groups by the importance of health subdimension before the SRFH program $(P>0.05)$, experimental group's posttest scores were higher and a significant difference was found between the groups $(P=0.03)$. Experimental group's postSRFH program importance of health subdimension scores increased and this difference was found statistically significant $(P=0.02)$. The self-awareness subdimension pretest scores were found similar in the experimental and control groups $(P>0.05)$. Experimental group's postSRFH program self-awareness scores were higher than the scores of the control group and the difference between the groups was found statistically significant $(P=0.03)$. The center of control subdimension posttest scores were not found significantly different between the groups $(P=0.76$; $P=0.17$ ). A statistically significant difference was found in the subdimension of Importance of Health between the percent of change of the experimental and control groups $(P=0.02)$ (Table III).

\section{Discussion}

The SRFH program increased adolescents' scores of empathic skill, altruism and health perception and created statistically significant differences between the experimental and control groups except for altruism. While several positive impacts of social responsibility programs on students were observed in the literature review, no study performed with adolescents under the leadership of a school nurse was observed. This study is important due to setting example for a SRFH program conducted under the leadership of a school nurse.

Every individual has the potential and responsibility to influence the development of their environment within their own limits and they are obliged to create values while benefiting from them [3]. The social responsibility programs to be carried out with students are important for having them attain these values. A school nurse is an important member of the school community $[19,20]$. Social responsibility programs should benefit both the student and the society. Observation and cooperation are critical when an effective program is ready. The program should be developed in accordance with society's needs. Students should embrace, participate actively and be decision makers. Theoretical instructions and applied practices should be conducted together and included in the curriculum in the studies [15]. This study was prepared and implemented based on the literature. Students' ideas and suggestions were involved in the SRFH program. In the literature review, it is seen that most of the research on this subject is definitive. Interventional studies in small numbers have limited sample size and implementation durations. It can be said that the distinctive feature of this study is that the SRFH program was implemented by the school nurse uninterruptedly during an academic term, the participants were asked for opinions and the program was applied by experiencing and observing. Furthermore, the fact that the adolescents in the experimental group visited children and other adolescents that can be considered their peers might have increased the success of the program. In those visits, how the adolescents communicated with their patient/disabled peers might have enhanced their empathic skills and how they shared the music and gifts they produced might have improved their altruistic behaviors. It had been aimed with the visits within the scope of the program that the adolescents would think over their health during the time they would spend with their peers with health problems and review their health behaviors. It is thought that this attempt aiming to create awareness of their own health had also a positive impact on adolescents' health perceptions.

In accordance with the findings achieved in the study, whereas there was no difference between the experimental and control groups by their empathic skill levels prior to the SRFH program, a statistically significant difference was discovered afterwards. Moreover, experimental groups' empathic skill scores increased. In a study, it was reported that the high school students had moderate empathic skill levels and the study emphasized the importance of applications and programs outside the classroom for the development of empathic skill [21]. There are other studies suggesting that individual's empathic skills can be improved and they can be provided with empathic skill through theoretical education [22]. Theoretical education was also included in the SRFH program, too. Children need to experience empathy to develop empathy towards others [23]. It has been reported that learning by experiencing is the most useful method to improve empathy [24]. The reason for the increased 
empathic skill in the findings of this study may be the school and hospital visits, time spent with patients and students and the learning by experiencing method. Another point which was also emphasized was the importance of interactive club activities which increased students' social skills in school programs [25]. In this study, too, interactive courses were utilized, and it was observed that empathy was improved. It is recommended in the literature that interventional studies are conducted for improving students' empathy. It has been reported in the interventional studies conducted by Y1lmazBingöl and Uysal, Olowokere and Okanlawon and Karaca et al. that there was an increase in the empathy levels of the experimental group [26-28]. The findings of this study comply with the literature and are similar to other studies in the literature due to being an interventional study and increasing the empathy positively. The fact that the SRFH program was implemented in adolescence during which peer relations are in the forefront and it allowed the adolescents to communicate with their disadvantaged peers face to face might have improved empathic skills of the adolescents in the experimental group. However, the sample size of this study is differently larger than other studies.

Another finding of the study is that the significant difference in altruism levels of the adolescents in the experimental group to which the SRFH program was applied remained in the posttests. An increase in the altruism levels of the experimental group was also observed. In the literature, it is known that altruism is a teachable behavior and programs planned for positive social behaviors are effective in increasing the altruism levels [29, 30]. It is also seen in this study that the adolescents embraced the altruistic behavior. This finding is parallel with the literature. In a study, it was reported that the adolescents had moderate altruism levels and the eight-session program applied for increasing altruism through group education increased adolescents' altruism levels [31]. The findings of this study showed that interventional programs enhance the altruism levels, which coincided with the literature. However, the SRFH program differed from other programs because it was completed in a long period which was 14 sessions and the adolescents in the experimental group shared some activities and suprises voluntarily with their patient peers (mini guitar concert, handmade surprises). The increased altruism scores of the experimental group after the SRFH program made one think that the program was effective. The reason why there was a difference between the experimental and control groups prior to the program might be that the control group had participated in school's club activities obligatory in the past and during the program implementation period. The students are obliged to work in projects such as aid to schools, book collection etc. even if they are not related to health within the scope of the club activities. It is known that such projects have an impact on altruism score [31]. It can be thought that the Social Responsibility for Health project enhanced the altruism behavior whereas all social responsibility projects improve the altruistic behavior in general.

While there was no difference between the groups by adolescents' health perception and subdimension scores prior to the SRFH program, statistically significant difference was discovered by the health perception and importance of health and self-awareness subdimensions in the posttest. Total health perception score and the importance of health subdimension score increased in the experimental group. When considering the examples in the literature similar to our study, it was stated in a study which determined that adolescent educational program influenced risky health behaviors and health that the education was effective in improving the positive health perception. In a study performed by Kürtüncü et al., in which they examined the effect of the adolescent educational program on risky health behaviors and health perception, it was reported that health perception increased through this program [32]. In another definitive study examining the health perception, majority of the adolescents reported that they perceived their health on a "good level" and they have faith in controlling their health in future [33]. In this study, too, it was discovered that the adolescents had a moderate health perception but it increased in the experimental group following the program. The reason might be that the adolescents discussed what they can do to protect/enhance their health through the activity videos they recorded during the program under the leadership of the school nurse. Moreover, visiting the institutions might have allowed them to think about their own health. The scope of the program mainly included objectives toward the importance of health and limited coverage of the objectives toward other subdimensions in the program might be the reason why no difference was observed by these subdimensions.

\section{Conclusion}

The SRFH program implemented under the leadership of a school nurse created increased adolescents' empathic skills and health perception and created a difference between the experimental and control groups. However, in the experimental group, the total score of altruism and the scores of social and helpfulness subdimensions increased 
while the program did not make any difference between the experimental and control groups in the posttest.

It can be recommended that the SRFH program is included in school curricula and social responsibility projects for health are added to the studies conducted by school nurses.

\section{References}

1. Atabek E. "Gençlerdeki Şiddet". Cumhuriyet Gazetesi arşivi, 2005; 25 Mayis, http://cumhuriyetarsivi.com/katalog/192/ yazar/296/1999/5/24.xhtml. Assecced: 4 July, 2017.

2. Düzgüner S. Değişen dünyada gençlik ve değerler. Gençlik Araştırmaları Derg 2015; 3: 105-26.

3. Şirin H. Öğrencilerin sosyal sorumluluklarının geliştirilmesinde öğretmenlerin rolü. Gazi Eğitim Fak Derg 2005; 25: 301-16.

4. Saran M, Coşkun G, Zorel Fİ, Aksoy Z. Üniversitelerde sosyal sorumluluk bilincinin geliştirilmesi. Ege Üniversitesi topluma hizmet uygulamaları üzerine bir araştırma. J Yaşar Univ 2011; 22: 3732-47.

5. Hotamışlı M, Çağ A, Menteşe A, Yörük E. Kurumsal sosyal sorumluluk bilinci: Afyon Kocatepe Üniversitesi'nde karşılaş̧ırmalı bir araştırma. J Soc Sci (Electronic) 2010; 9: 280-99. http://dergipark.gov.tr/esosder Accessed: 4 July, 2017.

6. Töremen F. Öğretmen adaylarının sorumluluk eğitimi. Kuram ve Uygulamada Eğitim Bilimleri Dergisi 2011;1: 263-77.

7. Bulut B, Kara C. Sosyal Bilgiler dersinde topluma hizmet uygulamaları ve sosyal kulüplerle değerler eğitimi. IV. Uluslararası Türkiye Eğitim Araştırmaları Kongresi; 2012 4-7 Mayıs, İstanbul, Türkiye; Kongre Kitabcığı 2012;1620-25.

8. Carlo G, Hausmann A, Christiansen S, Randall BR. Sociocognitive and behavioral correlates of a measure of prosocial tendencies for adolescents. J Early Adolesc 2003; 23: 10734. doi:10.1177/0272431602239132

9. Elma C, Kesten A, Kıroğlu K, Uzun EM, Dicle AN, Palavan Ö. Öğretmen adaylarının topluma hizmet uygulamaları dersine ilişkin algıları. Kuram ve Uygulamada Eğitim Bilimleri Dergisi 2010; 16: 231-52.

10. Moely BE, McFarland M, Miron DM, Mercer S, Ilustre V. Change in college students's attitudes and intentions for civic involvement as a function of service-learning experiences. Michigan Journal of Community Service Learning 2002;9:1826. http://hdl.handle.net/2027/spo.3239521.0009.102 Accessed: 1 November, 2017.

11. Ünal F. Öğretmen adaylarının sosyal sorumluluk projelerinin topluma kattığı değer hakkındaki görüşleri. 1. Ulusal İyilik Sempozyumu 20-21 Haziran 2009. Elazığ, Türkiye.

12. Cartwright A. Science service learning. J Chem Educ 2010; 8:1009-10. doi:10.1021/ed100708d

13. Ersanlı, E. Bireyin iç huzur kazanmasında cem törenlerinin etkisi. Türk Kültürü ve Hac1 Bektaş Veli Araştırma Derg 2011; 58: 105-10. http:/www.hbvdergisi.gazi.edu.tr/index.php/ TKHBVD/article/view/1911 Accessed: 1 November, 2017.
14. Beydoğan Ö. Okullarda uygulanan sosyal ve kültürel etkinliklerin öğrencilerin değer edinimine etkisi. Gaziantep Univ Journal of Social Sciences 2012; 11: 1172 - 204.

15. Uğurlu Z, Kıral E. Öğretmen adaylarının topluma hizmet uygulamaları dersinin işleyişs süreci ve kazanımlarına ilişskin görüşleri. Karabük Univ Sosyal Bilimler Enstitüsü Derg 2012; 1: 720-34. (2 nd International Conference on New Trends in Education and Their Implications; 2011 27-29 April; Antalya,Turkey 2011 www.iconte.org).

16. Dökmen, Ü. Empatinin yeni bir modele dayanılarak ölçülmesi ve psikodrama ile geliştirilmesi. Ankara Univ Eğitim Bilimleri Fakültesi Derg 1988; 21: 155-90. doi:10.1501/ Egifak_0000000999.

17. Akbaba S. Özgecilik ölçeğinin Türkçe'ye uyarlanması geçerlik ve güvenirlik çalışması. Atatürk Univ Erzincan Eğitim Fak Derg 2001; 3: 85-95.

18. Kadığlu H, Yıldız A. Sağlık Algısı ölçeğinin Türkçe çevriminin geçerlilik ve güvenilirliği. Türkiye Klinikleri 2012; 32: 47-53. doi: 10.5336/medsci.2010-21761.

19. Bahar Z, Haney MÖ. Okul sağlığı hemşireliği: okul dönemindeki çocukların sağlığının geliştirilmesi. Sebahat Gözüm, ed. 1. Bask1, Ankara: Vize Yayıncılık, 2016:10-19.

20. Ergül FH, Kurtulmuş M. Sosyal sorumluluk anlayıșının geliştirilmesinde topluma hizmet uygulamaları dersine ilişkin öğretim elemanlarının görüşleri. Elektronik Sosyal Bilimler Derg 2014;13: 221-32. doi: 10.17755/esosder.72162.

21. Durakoğlu A, Gökçearslan Ş. Lise öğrencilerinin empatik eğilim düzeyinin çeşitli değişkenlerle ilişkisi. E-Journal Of New World Sciences Academy 2010; 5: 354 - $64 \mathrm{http}: / /$ dergipark.ulakbim.gov.tr/nwsaedu/article/ view/5000063422/5000059571 Accessed: 4 July, 2017.

22. Kemeny ME, Foltz C, Cavanagh JF, Cullen M, Giese Davis J, Jennings P. Contemplative / emotion training reduces negative emotional behavior and promotes prosocial responses. Emotion 2012; 12: 338-50. doi: 10.1037/ a0026118

23. Calder J. Nurturing empathy. Child care health connections. A Health and Safety Newsletter for California Child Care Professionals 2010; 23: 1-8.

24. Çınar N, Cevahir R, Şahin S, Sözeri C, Kuğuluoğlu S. Evaluation of the empathic skills of nursing students with respect to the classes they are attending. Revista Electonica de Enfermagem 2007; 9: 588 - 95.http://www.fen.ufg.br/ revista/v9/n3/v9n3a03.htm Accessed: 4 July, 2017.

25. Büyükcebeci A, Deniz ME. Adolescents' social exclusion, loneliness and subjective well-being in school: mediating role of emphatic tendency. International Online Journal of Educational Sciences 2017; .http://www.iojes.net/ Accessed: 4 July, 2017.

26. Yılmaz-Bingöl T, Uysal R. Empati geliştirme grup rehberliği programının ilkokul ikinci sınıf öğrencilerinin empati düzeylerine etkisi. İlköğretim Online 2015; 14:430-37. http:// dergipark.ulakbim.gov.tr/ilkonline/article/view/5000113358 Accessed: 4 July, 2017. doi: 10.17051/io.2015.90489.

27. Olowokere AE, Okanlawon FA. The effects of a schoolbased psychosocial intervention on resilience and health outcomes among vulnerable children. J Sch Nurs 2014; 30: 206-15. doi: 10.1177/1059840513501557 
28. Karaca A, Açıkgöz F, Akkuş D. Eğitim ile empatik beceri ve empatik eğilim geliştirilebilir mi?: Bir sağlık yüksekokulu örneği. Acıbadem Univ Sağlık Bilimleri Derg 2013; 4:11822. http://www.acibadem.dergisi.org/pdf.php3?id=192 Accessed: 1 November, 2017.

29. Wallmark E, Safarzadeh K, Daukantaite D, Maddux RE. Promoting altruism through meditation: an 8-week randomized controlled pilot study. Mindfulness 2013; 4: 22334. doi:10.1007/s12671-012-0115-4.

30. Roeser RW, Pinela C. Mindfulness and compassion training in adolescence: A developmental contemplative science perspective. New Directions for Student Leadership 2014; 9-30. doi: 10.1002/yd.20094.
31. Bal N, Topuz C. Özgeciliği artırmaya yönelik psikoeğitim programının üniversite öğrencilerinin özgecilik düzeylerine etkisi. Eğitim ve Öğretim Araştırmaları Derg 2015; 4: 20616.

32. Kürtüncü M, Uzun M, Ayoğlu FN. Ergen eğitim programının riskli sağlık davranışları ve sağlı algısına etkisi. Yükseköğretim ve Bilim Derg 2015; 5: 187-95. doi: 10.5961/ jhes.2015.121.

33. Şimşek H, Öztoprak D, İkizoğlu E, Safaıl F. Tıp Fakültesi öğrencilerinde sağlıklı yaşam biçimi davranışları ve ilişkili etmenler. DEÜ Tıp Fakültesi Derg 2012; 26: 1517. URI: https://dspace.deu.edu.tr/xmlui/handle/12345/3880 Accessed: 1 November, 2017. 